open space

\title{
96 you and me do not start here
}

\author{
Nirmal Puwar
}

You and me do not start here,

in the racist taunts of the playground.

There was an imperial gate,

there was an imperial city.

There were ships,

there was trade.

There were shootings,

there were armies.

There were

bodies you needed for your armies

hands you needed for your labouring factories.

you and me start here.

\section{author biography}

Nirmal Puwar's publications include the book Space Invaders: Race, Gender and Bodies Out of Place (2004, Berg). She has co-edited several collections including: South Asian Women in the Diaspora (2003, Berg) with P. Raghuram; a Special Issue of the journal Fashion Theory on 'Orientalism' with N. Bhatia; a collection on 'Intimacy in Research' (2008) for the journal The History of the Human Sciences with M. Fraser; and the edited issue 'Post-colonial Bourdieu' in the Sociological Review with L. Back and A. Haddour (2009). 